\title{
Invasion and increased expression of S100A4 and CYR61 in mesenchymal transformed breast cancer cells is downregulated by GnRH
}

\author{
CARSTEN GRÜNDKER, GERD BAUERSCHMITZ, ANTJE SCHUBERT and GÜNTER EMONS
}

Department of Gynecology and Obstetrics, Georg-August-University, D-37075 Göttingen, Germany

Received February 9, 2016; Accepted March 17, 2016

DOI: $10.3892 /$ ijo.2016.3491

\begin{abstract}
S100 calcium binding protein A4 (S100A4) and cysteine-rich angiogenic inducer 61 (CYR61) play important roles in epithelial-mesenchymal-transition (EMT), invasion and metastasis by promoting cancer cell motility. Recently we were able to show that invasion of $\mathrm{GnRH}$ receptor-positive breast cancer cells is time- and dose-dependently reduced by $\mathrm{GnRH}$ analogs. We have now analyzed whether GnRH treatment affects S100A4 and CYR61 in mesenchymal transformed breast cancer cells. S100A4 and CYR61 expression was analyzed using RT-PCR. Invasion was quantified by assessment of breast cancer cell migration rate through an artificial basement membrane. The role of S100A4 and CYR61 in invasion of breast cancer cells was analyzed by neutralizing their biological activity. Expression of S100A4, CYR61 and GnRH receptor in human breast cancers, normal and other non-malignant breast tissues was analyzed by immunohistochemistry. Invasion and expression of S100A4 and CYR61 in MDA-MB-231 breast cancer cells were significant higher as compared with MCF-7 breast cancer cells. Invasion and expression of S100A4 and CYR61 were significantly increased in mesenchymal transformed MCF-7 cells (MCF-7-EMT). The increased invasion of MCF-7-EMT cells could be reduced by anti-S100A4 and anti-CYR61 antibodies. In addition, invasion of MDA-MB-231 cells was decreased by anti-S100A4 and anti-CYR61 antibodies. Treatment of MCF-7-EMT and MDA-MB-231 cells with GnRH agonist Triptorelin resulted in a significant decrease of invasion and expression of S100A4 and CYR61. Both, S100A4 and CYR61 were found highly expressed in biopsy specimens of breast hyperplasia and malignant breast cancers. GnRH receptor expression was detectable in approximately $71 \%$ of malignant breast cancers. Our findings suggest that S100A4 and CYR61 play major roles in breast cancer invasion. Both, invasion and
\end{abstract}

Correspondence to: Dr Carsten Gründker, Department of Gynecology and Obstetrics, Georg-August-University, Robert-KochStreet 40, D-37075 Göttingen, Germany

E-mail: grundker@med.uni-goettingen.de

Key words: breast cancer, S100A4, cysteine-rich angiogenic inducer $61, \mathrm{GnRH}$, metastasis, invasion expression of S100A4 and CYR61 can be inhibited by GnRH treatment.

\section{Introduction}

S100 calcium binding protein A4 (S100A4) is controlled directly by the $\mathrm{Wnt} / \beta$-catenin signal pathway and is involved in a number of biological mechanisms, i.e. cell movement, surviving, differentiation, and organization of the cytoskeleton (1-5). In addition, S100A4 plays an important role in the biology of stem cells $(2,4,5)$. In S100A4 deficient mice tumor development and metastasis are suppressed (6). S100A4 is overexpressed in tumor cells with metastatic phenotype, while inhibition of S100A4 expression reduces the metastatic potential of tumor cells $(7,8)$.

Cysteine-rich angiogenic inducer 61 (CYR61, CCN1) is part of the $\mathrm{CCN}$ intercellular signaling protein family and has various physiological functions, which are strongly dependent on the respective tissue $(9,10)$. In some tissues integrin-dependent proliferation, migration and adhesion is induced by CYR61 (11). In addition, CYR61 can cause directed migration as chemoattractant $(12,13)$. Cyr61 has an important role during vascularization in embryonic development, angiogenesis, and wound healing $(10,14,15)$. In addition, CYR61 plays an important role in skeleton formation and development of the neural system $(14,15)$. Furthermore, CYR61 is involved in transformation processes of the extracellular membrane (16). CYR61-caused effects in tumor tissues depend also strongly on the respective kind of tissue and stage of the disease (17-23). In breast cancers CYR61 leads to increased vascularization of tumors, increased cell proliferation, increased migration and a general increase of tumorigenicity $(18,24)$. A significant connection between CYR61 overexpression and stage of cancer, tumor size, lymph node infestation, and poor survival prognosis can be determined for cancers such as breast cancer, glioma and squamous cell carcinoma $(18,20,24,25)$.

Between 50 and $60 \%$ of human breast cancers and in addition most breast cancer cell lines express receptors for gonadotropin-releasing hormone (GnRH) (26-29). Approximately $74 \%$ of triple-negative breast cancers express GnRH receptors (30). Previous work showed that invasion of breast cancer cells through an artificial basement membrane was increased when they were cocultured with human primary osteoblasts (hOB) (31). We demonstrated that invasion 
in vitro (31) and metastasis in vivo (32) of $\mathrm{GnRH}$ receptorpositive breast cancer cells was time- and dose-dependently reduced by GnRH analogs. We have now analyzed whether GnRH treatment affects S100A4 and CYR61 in mesenchymal transformed breast cancer cells.

\section{Materials and methods}

Cell lines and culture conditions. Human breast cancer cell lines MDA-MB-231 and MCF-7 (wild-type) and osteoblast-like osteosarcoma cell line MG63 were obtained from American Type Culture Collection (ATCC, Manassas, VA, USA). In order to guarantee the identity of the cell lines over the years, cells were expanded after purchase and aliquots were stored in liquid nitrogen. Every half year a new frozen stock was opened and expanded to carry out the experiments. Cells were cultured at $37^{\circ} \mathrm{C}$ in a humidified atmosphere of $5 \% \mathrm{CO}_{2}$ in air in phenol red-free Dulbecco's minimal essential medium (DMEM, PAA Laboratories $\mathrm{GmbH}$, Pasching, Austria) supplemented with $10 \%$ charcoal-stripped fetal calf serum (cs-FCS) from Allgaeu BioTech Service (Görisried, Germany).

Human tissues. To analyze expression of GnRH receptor, S100A4, and CYR61 in specimens of human breast cancers we used human tissue arrays (US Biomax, Inc., Rockville, MD, USA) containing paraffin-embedded human normal and malignant breast tissue specimens, whose characteristics are outlined in Table I. Informed consent for the use of human tissues was obtained in accordance with the ethics guidelines that were effective at the time of collection and processing.

Immunohistochemistry. The tissue array slides were deparaffinized and rehydrated. Antigens were retrieved by incubation with $0.01 \mathrm{M}$ citrate buffer ( $\mathrm{pH}$ 6.0) in a microwave $(700 \mathrm{~W})$ for $5 \mathrm{~min}$. Endogenous peroxidase activity was quenched by treatment with $3 \%$ hydrogen peroxide solution for 6 min. After washing in PBS, the slides were treated with polyclonal rabbit anti-human GnRH receptor antiserum (33), polyclonal rabbit anti-human S100A4 antibody (Abcam, Cambridge, UK), or polyclonal rabbit anti-human CYR61 antibody (Abcam) in a 1:10,000, 1:1,000, or 1:1,000 dilution, respectively in $1 \%$ BSA in $10 \mathrm{mM}$ Tris, $\mathrm{pH} 8.0,500 \mathrm{mM}$ $\mathrm{NaCl}$ and $0.1 \%$ Tween-20 (TBST) for $1 \mathrm{~h}$ and, after being washed, were detected with the ready-to-use secondary horseradish peroxidase-conjugated anti-rabbit IgG antibody detection system according to the instructions of the supplier (Zymed Laboratories, San Francisco, CA, USA). Controls were performed by substitution of the primary antiserum with pre-immune serum of the same rabbit (anti-human GnRH receptor) or by omission of the primary antibody. Counterstaining was performed using Meyer's hematoxylin for $10 \mathrm{sec}$. The slides were then dehydrated, cleared, mounted with Permount, and studied by light microscopy.

Co-culture and microinvasion assay. Invasion was measured by assessment of the breast cancer cell migration rate through an artificial basement membrane in a modified Boyden chamber, where the breast cancer cells and the MG63 cells were grown without direct cell-to-cell contact. The membrane of the cell culture insert (upper well) consisted of polycarbonate
(8- $\mu \mathrm{m}$ pore diameter, Millipore, Schwalbach, Germany) and was coated on ice with Matrige ${ }^{\circledR}$ [extracellular matrix (ECM) gel; Becton Dickinson Biosciences, Heidelberg, Germany] diluted 1:2 in serum-free DMEM. Breast cancer cells were seeded into the upper wells (inserts) of the chamber, while the MG63 cells were seeded into the lower wells. The cells were cultured in DMEM supplemented with $10 \%$ charcoal-stripped fetal calf serum (cs-FCS) without phenol red for $12 \mathrm{~h}$ to allow the cells to attach. Thereafter the upper wells were placed on top of the lower wells (time point $\mathrm{t}_{0}$ ) and the breast cancer cells were treated right away with increasing concentrations of GnRH agonist Triptorelin $\left(10^{-11}-10^{-5} \mathrm{M}\right)$ every $24 \mathrm{~h}$ for $96 \mathrm{~h}$, with polyclonal rabbit anti-human S100A4 antibody (Abcam; $15 \mu \mathrm{g} / \mathrm{ml}$ ) or with polyclonal rabbit anti-human CYR61 antibody (Abcam; $15 \mu \mathrm{g} / \mathrm{ml}$ ) for $96 \mathrm{~h}$. A non-specific polyclonal rabbit isotype control antibody was used as negative control (Abcam). After $96 \mathrm{~h}$ the invaded breast cancer cells under the membrane were counted. Controls were performed by omission of the MG63 cells.

Generation of aggressive MCF-7 cells. Mesenchymal transformed MCF-7 cells (MCF-7-EMT) were generated as described by Ziegler et al (34). Briefly, single-cell suspensions of wild-type MCF-7 cells (MCF-7 WT) were suspended at a density of 40,000 cells/ml in DMEM/F-12 containing $5 \mu \mathrm{g} / \mathrm{ml}$ insulin (Sanofi-Aventis, Frankfurt, Germany), $0.5 \mathrm{mg} / \mathrm{ml}$ hydrocortisone, 2\% B27 supplement (Invitrogen, Darmstadt, Germany), $20 \mathrm{ng} / \mathrm{ml}$ epidermal growth factor (EGF; Sigma, Deisenhofen, Germany), $20 \mathrm{ng} / \mathrm{ml}$ fibroblast growth factor-2 (FGF-2; Sigma), and 1\% penicillin/streptomycin (PAA Laboratories $\mathrm{GmbH}$ ) before incubation on ultralow adherence six-well plates $(2.5 \mathrm{ml}$ per plate; Corning, Lowell, MA, USA). For prolonged mammosphere culture (5-6 weeks) the cells were passaged weekly. Mammospheres were harvested, incubated with trypsin for $3 \mathrm{~min}$ at $37^{\circ} \mathrm{C}$, and dissociated with a 21-gauge needle. After checking for single cells, the cells were pelleted and suspended in mammosphere culture medium to 40,000 cells $/ \mathrm{ml}$ before culturing on ultralow adherence plates. To show changes in morphology, bright field images of living MCF-7 WT cells and MCF-7-EMT cells were taken.

Isolation of mRNA and cDNA synthesis. The cells were detached immediately with $0.5 \mathrm{~g}$ trypsin (Biochrom, Berlin, Germany) and 5 mmol EDTA in 1 liter PBS/bovine serum albumin. Total RNA was prepared by the RNeasy protocol (Qiagen, Hilden, Germany). The concentration of RNA in each sample was determined by photospectroscopy. First-strand cDNA was generated by reverse transcription of $1 \mathrm{mg}$ total RNA, using p(dT) 15 primers (Roche Diagnostics, Mannheim, Germany) with MMLV-reverse transcriptase, according to the instructions of the suppliers (Life Technologies, Karlsruhe, Germany). After determination of the concentrations of the cDNAs, the samples were used for PCR analysis. The integrity of the samples was tested by RT-PCR of the ribosomal housekeeping gene L7.

Semiquantitative PCR amplification. The cDNAs (2 ng) were amplified in a $50 \mu 1$ reaction volume containing $10 \mathrm{mM}$ Tris $/ \mathrm{HCl}(\mathrm{pH} 8.3), 50 \mathrm{mM}$ potassium chloride, $1.5 \mathrm{mM}$ 


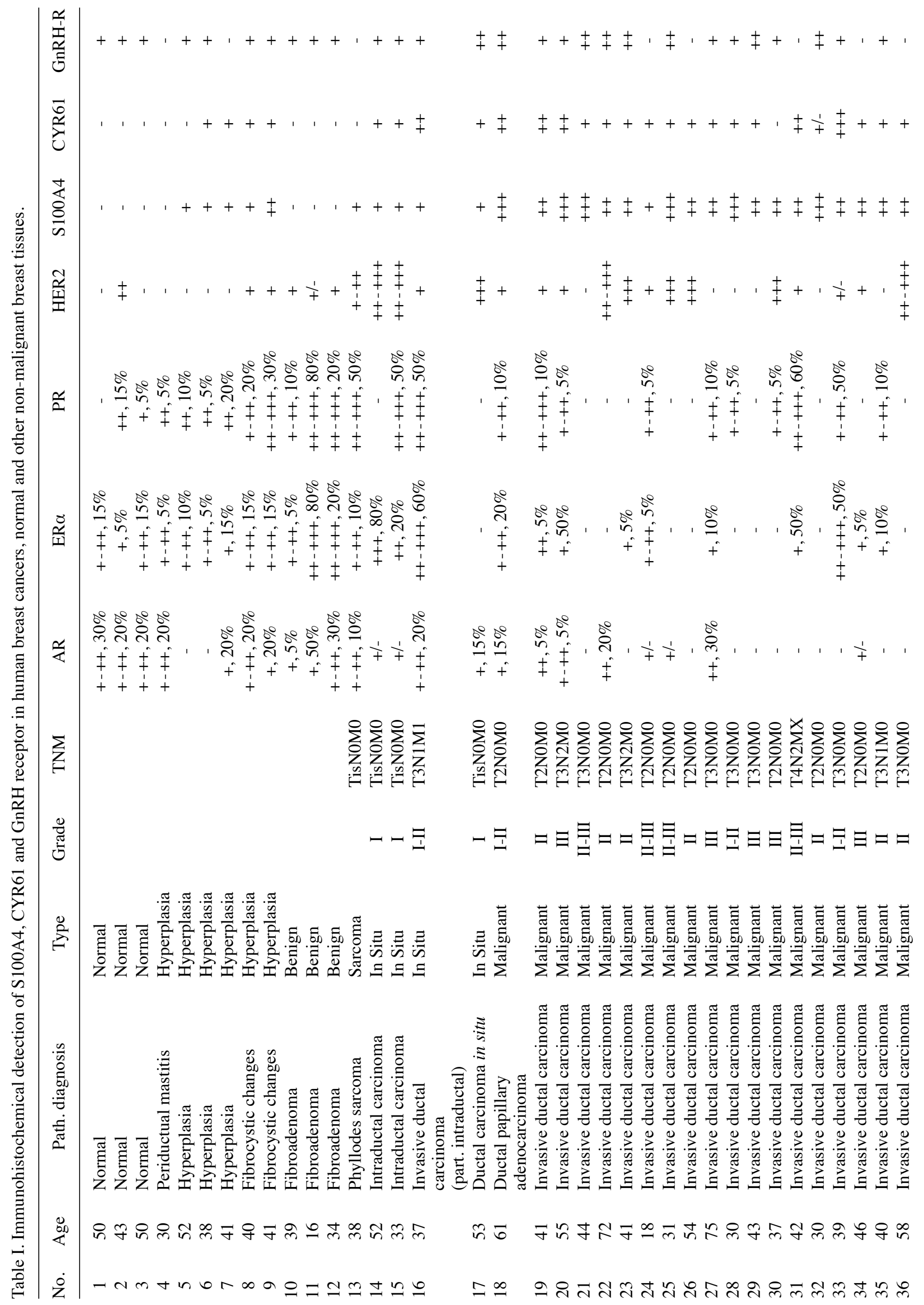




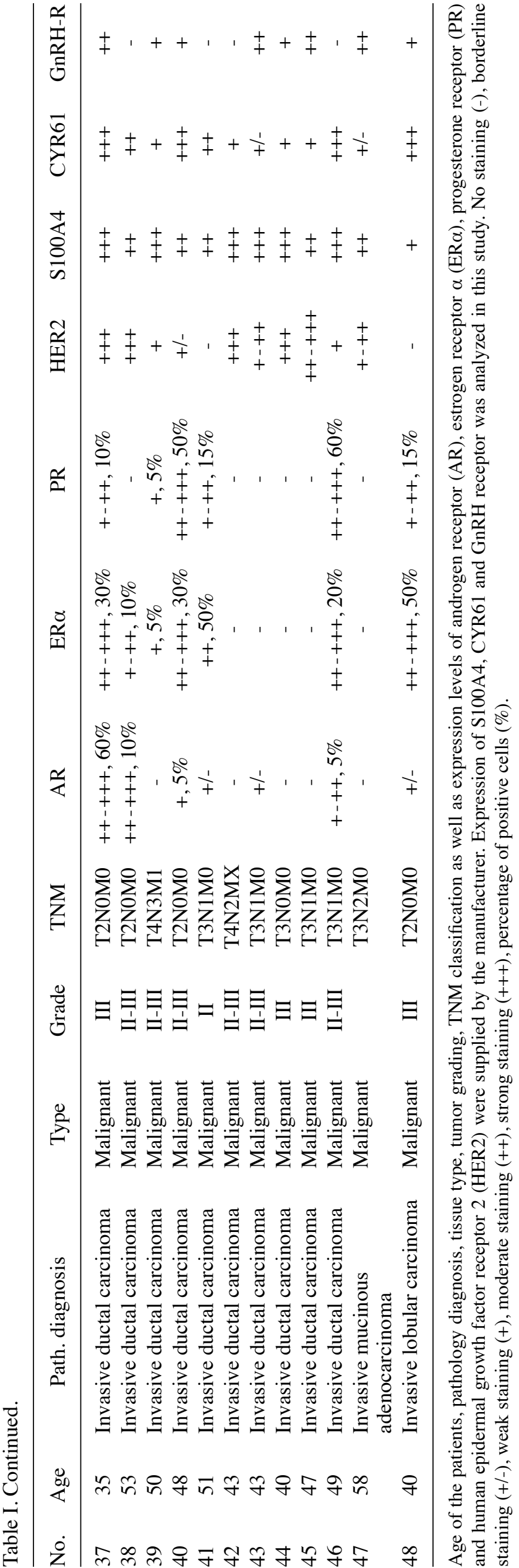

magnesium chloride, $200 \mathrm{mM}$ of each of the dNTPs, $1 \mathrm{mM}$ of the appropriate primers (S100A4 (239 bp): forward primer, 5'-TCT CTC CTC AGC GCT TCT TC-3'; backward primer, 5'-GCT GTC CAA GTT GCT CAT CA-3'; CYR61 (241 bp): forward primer, 5'-CTC CCT GTT TTT GGA ATG GA-3'; backward primer, 5'-TGG TCT TGC TGC ATT TCT TG-3'; L7 (357 bp), forward primer, 5'-AGA TGT ACA GAA CTG AAA TTC-3'; backward primer, 5'-ATT TAC CAA GAG ATC GAG CAA-3') and 1.25 U AmpliTaq Gold polymerase (Applied Biosystems, Weiterstadt, Germany) in an Applied Biosystems DNA thermal cycler 9600. Twenty-five (S100A4), 27 (CYR61) or 18 (L7) cycles of amplification representing the exponential phase of the PCR were carried out: Denaturation at $94^{\circ} \mathrm{C}$ for $60 \mathrm{sec}$; annealing at $58^{\circ} \mathrm{C}(\mathrm{S} 100 \mathrm{~A} 4), 55^{\circ} \mathrm{C}(\mathrm{CYR} 61)$ or $54^{\circ} \mathrm{C}$ (L7) for $60 \mathrm{sec}$; followed by extension at $72^{\circ} \mathrm{C}$ for $60 \mathrm{sec}$. The PCR products were separated by gel electrophoresis in $1.5 \%$ agarose and visualized by ethidium bromide staining on a UV transilluminator. For correct densitometric analysis, the S100A4 or the CYR61 fragment and the L7 fragment were run on the same gel. For quantification the bands were analyzed using a Biometra BioDoc Analysis system (Biometra, Göttingen, Germany). Expression levels were calculated in comparison with the expression levels of the control $(=100 \%)$. Expression levels of the housekeeping gene L7 were used for standardization.

Statistical analysis. All experiments were repeated at least three times with different passages of the respective cell lines. The data were tested for significant differences by un-paired two-tailed t-test or by one-way analysis of variance followed by Tukey's multiple comparisons test for comparison of individual groups, after a Bartlett test had shown that variances were homogeneous using GraphPad Prism 6.01 software (GraphPad Software Inc., La Jolla, CA, USA).

\section{Results}

Correlation of invasiveness and expression of S100A4 and CYR61. Invasion of MDA-MB-231 breast cancer cells measured by assessment of breast cancer cell migration rate through an artificial basement membrane in a modified Boyden chamber was 5-fold higher (588.8 $\pm 63.2 \%$ vs. MCF-7; $=100 \%$; $\mathrm{P}<0.001)$ as compared with MCF-7 breast cancer cells (Fig. 1A). Expression of S100A4 mRNA in MDA-MB-231 breast cancer cells was 4.7 -fold higher $(470.0 \pm 120.9$ vs. MCF-7; $=100 \% ; \mathrm{P}<0.05)$ as compared with MCF-7 breast cancer cells (Fig. 1B). CYR61 mRNA expression in MDA-MB-231 breast cancer cells was 7.2-fold higher (719.5 \pm 169.7 vs. MCF-7; $=100 \% ; \mathrm{P}<0.01)$ as compared with MCF-7 breast cancer cells (Fig. 1B).

Expression of S100A4 and effects of anti-S100A4 antibody treatment on invasion of MCF-7-EMT and MDA-MB-231 cells. Mesenchymal transformed MCF-7 cells (MCF-7-EMT) showing significantly increased invasion in contrast to wild-type MCF-7 (MCF-7 WT) cells were generated using prolonged mammosphere culture $(34,35)$. Expression of S100A4 mRNA in MCF-7-EMT cells was significantly increased to $165.1 \pm 21.0 \%$ as compared with MCF-7 WT cells $(=100 \%$; $\mathrm{P}<0.05)$ (Fig. 2A). 

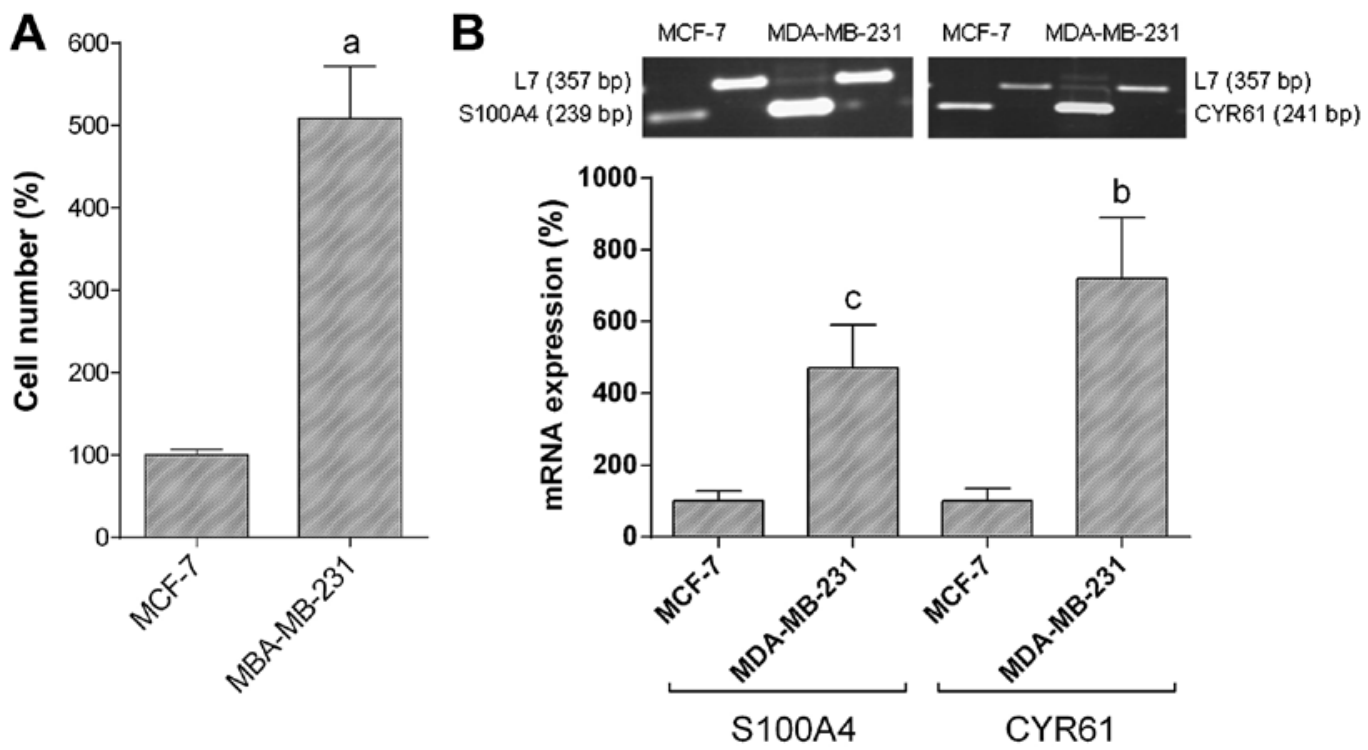

Figure 1. (A) Invasiveness of MCF-7 and MDA-MB-231 human breast cancer cells. Number of invaded MCF-7 and MDA-MB-231 breast cancer cells cultured in a modified Boyden chamber. Columns represent means \pm SEM of data obtained from eight independent experiments in eight different passages of each cell line. a, P<0.001 vs. MDA-MB-231 (unpaired t-test, two-tailed). (B) Expression of S100A4 and CYR61 in MCF-7 and MDA-MB-231 human breast cancer cells. Quantification of S100A4 and CYR61 mRNA expression of MCF-7 and MDA-MB-231 human breast cancer cells. Expression levels of the housekeeping gene L7 were used for standardization. Columns represent means \pm SEM of data obtained from six independent experiments in six different passages of the cell lines. b, $\mathrm{P}<0.01$ vs. MDA-MB-231; c, $\mathrm{P}<0.05$ vs. MDA-MB-231 (unpaired t-test, two-tailed).
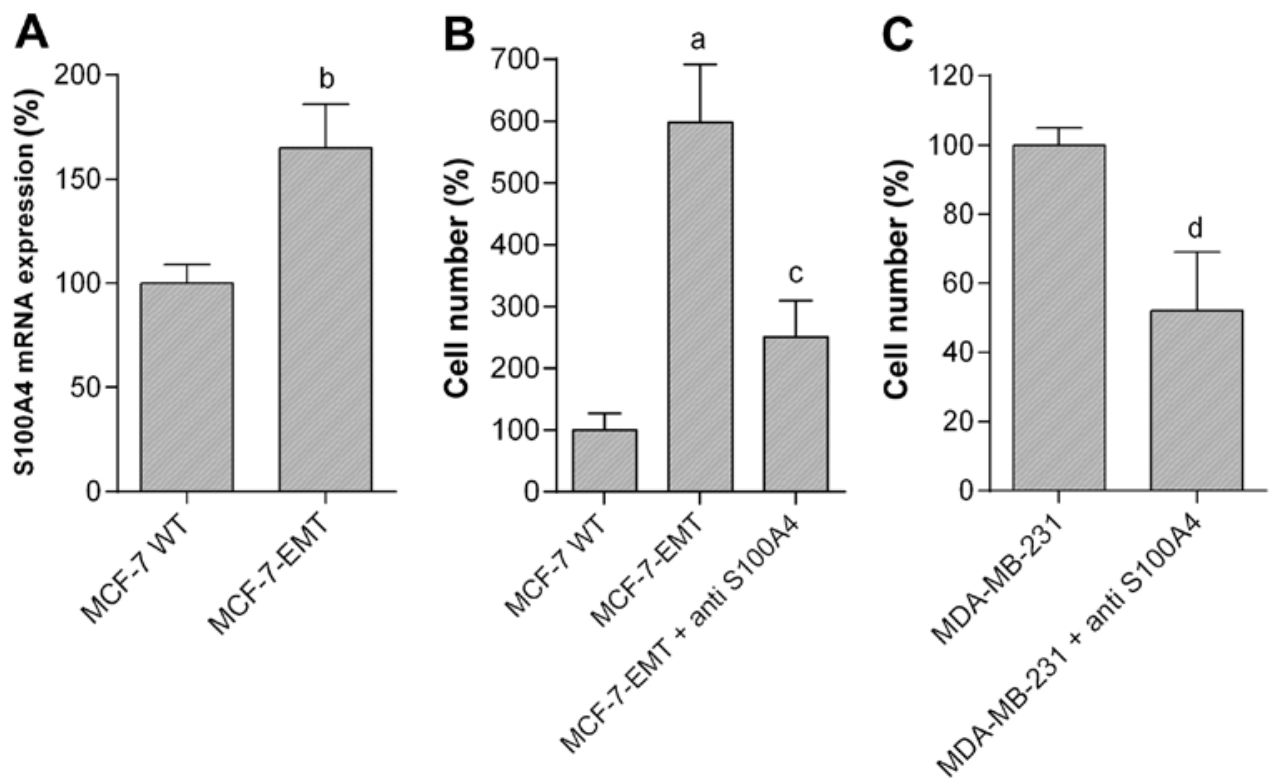

Figure 2. (A) Expression of S100A4 in MCF-7 WT and MCF-7-EMT human breast cancer cells. Quantification of S100A4 mRNA expression of wild-type MCF-7 (MCF-7 WT) and mesenchymal transformed MCF-7-EMT cells. Expression levels of the housekeeping gene L7 were used for standardization. Columns represent means \pm SEM of data obtained from six independent experiments in six different passages of the cell lines. b, P $<0.05$ vs. MCF-7 WT (unpaired t-test, two-tailed). (B and C) Effects of anti-S100A4 antibody treatment on invasion of MCF-7-EMT and MDA-MB-231 cells. (B) Number of invaded MCF-7 WT and MCF-7-EMT cells cultured in a modified Boyden chamber without or with $96 \mathrm{~h}$ of treatment with anti-S100A4 antibody (15 $\mu \mathrm{g} / \mathrm{ml})$. (C) Number of invaded MDA-MB-231 cells cultured in a modified Boyden chamber without or with $96 \mathrm{~h}$ of treatment with anti-S100A4 antibody (15 $\mu \mathrm{g} / \mathrm{ml})$. Columns represent means \pm SEM of data obtained from six independent experiments in six different passages of the cell lines. a, P<0.001 vs. MCF-7 WT; c, P $<0.01$ vs. MCF-7-EMT (ANOVA followed by Tukey's multiple comparisons test); d, $\mathrm{P}<0.05$ vs. untreated MDA-MB-231 (unpaired t-test, two-tailed).

To emphasize the importance of S100A4 we observed the invasiveness of MCF-7-EMT and MDA-MB-231 breast cancer cells after treatment with anti-human S100A4 antibody (Fig. 2B and C). MCF-7-EMT cells cultured in a modified Boyden chamber showed significant increased invasion in contrast to the wild-type cells (Fig. 2B). Invasion of
MCF-7-EMT cells was 6-fold higher (598.3 $\pm 94.5 \%$ vs. MCF-7 WT; P<0.001) in comparison to MCF-7 WT cells. Treatment with S100A4 antibody led to a significant decrease of invaded MCF-7-EMT cells to $251.1 \pm 59.2 \%$ of control $(\mathrm{P}<0.01$ vs . MCF-7-EMT) (Fig. 2B). The naturally high invasiveness of MDA-MB-231 cells was reduced to $52.4 \pm 17.2 \%$ of control 

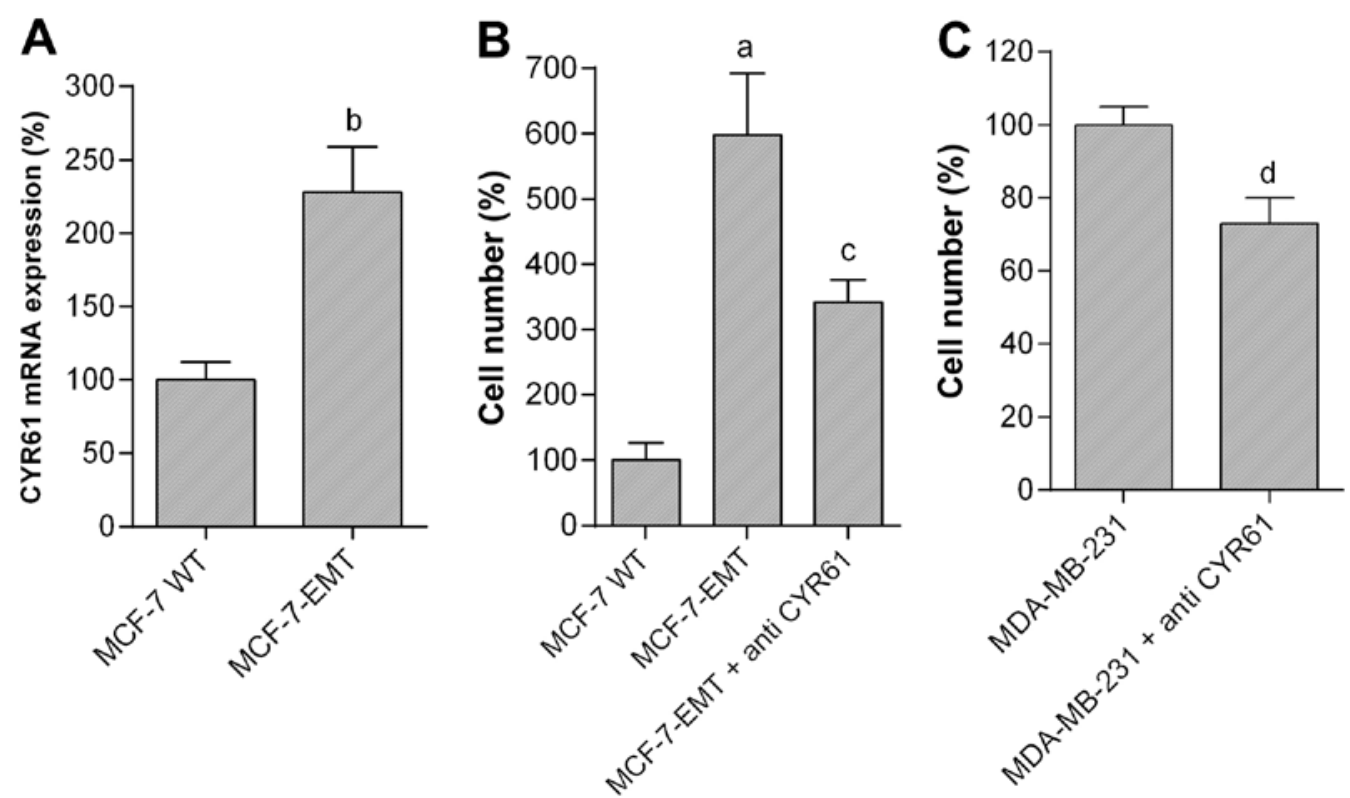

Figure 3. (A) Expression of CYR61 in MCF-7 WT and MCF-7-EMT human breast cancer cells. Quantification of CYR61 mRNA expression of wild-type MCF-7 (MCF-7 WT) and mesenchymal transformed MCF-7-EMT cells. Expression levels of the housekeeping gene L7 were used for standardization. Columns represent means \pm SEM of data obtained from six independent experiments in six different passages of the cell lines. b, P $<0.05$ vs. MCF-7 WT (unpaired t-test, two-tailed). (B and C) Effects of anti-CYR61 antibody treatment on invasion of MCF-7-EMT and MDA-MB-231 cells. (B) Number of invaded MCF-7 WT and MCF-7-EMT cells cultured in a modified Boyden chamber without or with $96 \mathrm{~h}$ of treatment with anti-CYR61 antibody (15 $\mu \mathrm{g} / \mathrm{ml})$. (C) Number of invaded MDA-MB-231 cells cultured in a modified Boyden chamber without or with $96 \mathrm{~h}$ of treatment with anti-CYR61 antibody (15 $\mu \mathrm{g} / \mathrm{ml})$. Columns represent means \pm SEM of data obtained from six independent experiments in six different passages of the cell lines. a, P $<0.001 \mathrm{vs.} \mathrm{MCF-7} \mathrm{WT;} \mathrm{c,} \mathrm{P}<0.01 \mathrm{vs}$. MCF-7-EMT (ANOVA followed by Tukey's multiple comparisons test); $\mathrm{d}, \mathrm{P}<0.05$ vs. untreated MDA-MB-231 (unpaired t-test, two-tailed).

$(=100 \% ; \mathrm{P}<0.001)$ after treatment with S100A4 antibody (Fig. 2C). Controls using a non-specific isotype control antibody showed no effects (not shown).

Expression of CYR61 and effects of anti-CYR61 antibody treatment on invasion of MCF-7-EMT and MDA-MB-231 cells. Expression of CYR61 mRNA in MCF-7-EMT cells was significantly increased to $228.2 \pm 30.9 \%$ as compared with MCF-7 WT cells $(=100 \%$; P<0.01) (Fig. 3A). To analyze the role of CYR61 we observed the invasiveness of MCF-7-EMT and MDA-MB-231 breast cancer cells after treatment with anti-human CYR61 antibody (Fig. 3B and C). The 6-fold increased invasion of MCF-7-EMT cells in comparison to MCF-7 WT cells $(598.3 \pm 94.5 \%$ vs. MCF-7 WT; $\mathrm{P}<0.001)$ was significantly decreased to $341.4 \pm 35.3 \%$ of control $(\mathrm{P}<0.05$ vs. MCF-7-EMT) after treatment with CYR61 antibody (Fig. 3B). The naturally high invasiveness of MDA-MB-231 cells was reduced to $73.1 \pm 7.0 \%$ of control $(=100 \%$; $\mathrm{P}<0.05)$ after treatment with CYR61 antibody (Fig. 3C). Controls using a non-specific isotype control antibody showed no effects (not shown).

Effects of GnRH agonist treatment on invasion and expression of S100A4 and CYR61. In the GnRH receptor-positive breast cancer cell lines MCF-7-EMT (Fig. 4A) and MDA-MB-231 (Fig. 4D), the number of invaded cells was dose-dependently reduced by 5 days of treatment with increasing concentrations $\left(10^{-11}-10^{-5} \mathrm{M}\right)$ of $\mathrm{GnRH}$ agonist Triptorelin.

At $10^{-11} \mathrm{M}$ Triptorelin concentration a slight decrease in number of invaded MCF-7-EMT cells to $73.2 \pm 9.1 \%$ of control (=100\%; not significant) was observed (Fig. 4 A). At $10^{-9} \mathrm{M}$ concentration of Triptorelin, the reduction in cell number was significant $(55.8 \pm 10.9 \%$ of control; $100 \%$; $\mathrm{P}<0.05)$. At $10^{-7} \mathrm{M}$ Triptorelin concentration a significant decrease in number of invaded MCF-7-EMT cells to $42.0 \pm 7.9 \%$ of control $(100 \%$; $\mathrm{P}<0.01)$ was observed. Triptorelin at $10^{-5} \mathrm{M}$ had almost the same inhibitory effects on cell invasion $(38.7 \pm 12.5 \%$ of control $(100 \% ; \mathrm{P}<0.01)$.

At $10^{-11} \mathrm{M}$ Triptorelin concentration the number of invaded MDA-MB-231 cells was slightly decreased to $75.1 \pm 16.8 \%$ of control (100\%; not significant) (Fig. 4D). At $10^{-9} \mathrm{M}$ concentration of Triptorelin the number of invaded MDA-MB-231 cells was reduced to $67.2 \pm 5.4 \%$ of control (100\%; not significant). The inhibitory effects were maximal at $10^{-7} \mathrm{M}$ concentration of Triptorelin and corresponded to $53.1 \pm 5.8 \%$ of control $(100 \% ; \mathrm{P}<0.05)$. Triptorelin at $10^{-5} \mathrm{M}$ showed comparable inhibitory effects on cell invasion $(58.9 \pm 10.7 \%$ of control (100\%; $\mathrm{P}<0.05)$.

To analyze whether GnRH plays a role in S100A4 and CYR61 function, MCF-7-EMT (Fig. 4B and C) and MDA-MB-231 (Fig. 4E and F) cells were treated with GnRH agonist Triptorelin and mRNA expression of S100A4 and CYR61 was measured. After $48 \mathrm{~h}$ of treatment with Triptorelin $\left(10^{-7} \mathrm{M}\right) \mathrm{S} 100 \mathrm{~A} 4 \mathrm{mRNA}$ expression in MCF-7-EMT cells was significantly reduced to $53.2 \pm 14.7 \%$ of control $(100 \% ; \mathrm{P}<0.05)$ (Fig. 4B). Expression of CYR61 mRNA in MCF-7-EMT cells was significantly decreased to $33.1 \pm 10.8 \%$ of control $(100 \%$; $\mathrm{P}<0.01$ ) (Fig. 4C). Treatment of MDA-MB-231 cells with $10^{-7} \mathrm{M}$ Triptorelin for $48 \mathrm{~h}$ resulted in a significant decrease of S100A4 mRNA expression to $68.7 \pm 7.1 \%$ of control (100\%; $\mathrm{p}<0.05$ ) (Fig. 4E), whereas CYR61 mRNA was significantly reduced to $45.0 \pm 11.9 \%$ of control (100\%; $\mathrm{P}<0.01)$ (Fig. 4F). 

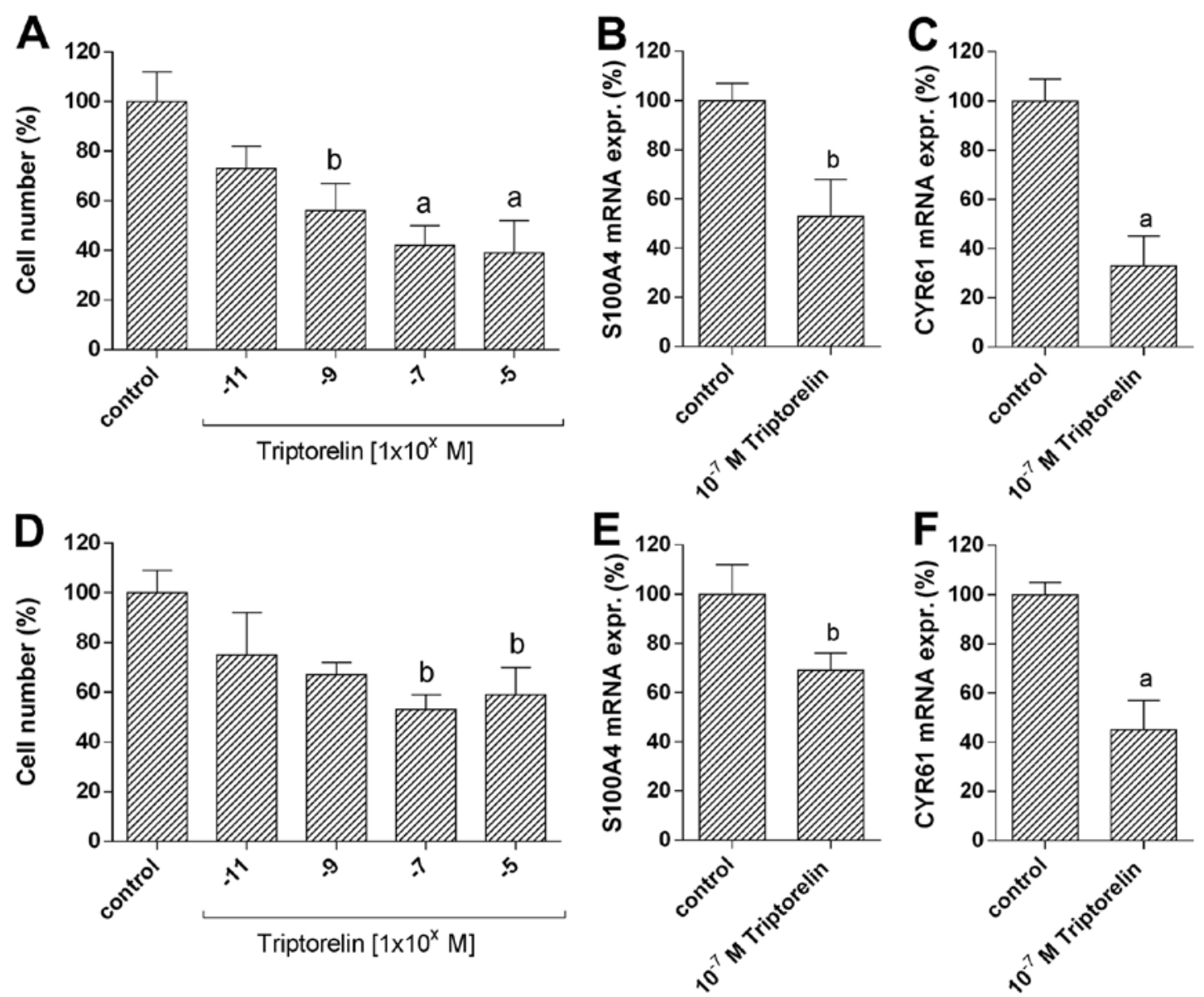

Figure 4. Effects of GnRH agonist Triptorelin treatment on invasion and expression of S100A4 and CYR61. Number of invaded MCF-7-EMT (A) and MDAMB-231 (D) cells cultured in a modified boyden chamber after 5 days of treatment with increasing concentrations of GnRH agonist Triptorelin $\left(10^{-11}-10^{-5} \mathrm{M}\right)$. Columns represent means \pm SEM of data obtained from six independent experiments in six different passages of the cell lines. a, $\mathrm{P}<0.01 \mathrm{vs}$. control; $b, \mathrm{P}<0.05$ vs. control (ANOVA followed by Tukey's multiple comparisons test). Quantification of S100A4 mRNA expression of MCF-7-EMT (B) and MDA-MB-231 (E) cells after $48 \mathrm{~h}$ of treatment without or with GnRH agonist Triptorelin $\left(10^{-7} \mathrm{M}\right)$. Quantification of CYR61 mRNA expression of MCF-7-EMT (C) and MDAMB-231 (F) cells after $48 \mathrm{~h}$ of treatment without or with GnRH agonist Triptorelin $\left(10^{-7} \mathrm{M}\right)$. Expression levels of the housekeeping gene L7 were used for standardization. Columns represent means \pm SEM of data obtained from six independent experiments in six different passages of the cell lines. a, $\mathrm{P}<0.01 \mathrm{vs}$. control; $b, \mathrm{P}<0.05$ vs. control (unpaired t-test, two-tailed).

Immunohistochemical detection of S100A4, CYR61 and GnRH receptor in human breast cancers, normal and other non-malignant breast tissues. Following data were given by the supplier of the tissue arrays (materials and methods section): Age of the patients, pathology diagnosis, tissue type, tumor grading, and TNM classification (Table I). Expression levels of androgen receptor (AR), estrogen receptor $\alpha$ (ER $\alpha$ ), progesterone receptor (PR) and human epidermal growth factor receptor 2 (HER2) were known (Table I).

In biopsy specimens of breast hyperplasia and malignant breast cancers S100A4 and CYR61 were found highly expressed (Table I). Carcinoma in situ showed lower expression of S100A4 and CYR61, whereas normal breast tissues and benign fibroadenoma were S100A4 and CYR61 negative. In most cases, high CYR61 expression, but not high S100A4 expression was correlated with high ER $\alpha$ expression. Benign fibroadenoma with high ER $\alpha$ expression remained CYR61 negative. Correlations to expression of AR, PR and HER 2 were not found. GnRH receptor expression was detectable in 4 of 6 cases of benign fibroadenoma (67\%), in 3 of 3 cases of benign fibroadenoma (100\%), in 4 of 4 cases of carcinoma in situ (100\%), and in 22 of 31 cases of malignant breast cancers (71\%).

\section{Discussion}

We have established a coculture model to mimic the in vivo invasion process and to analyze EMT $(31,36,37)$. Using this model we can induce non invading MCF-7 breast cancer cells to substantial invasion and thus to markedly increase the number of cells undergoing EMT $(31,34)$. By prolonged mammosphere culture we have generated a mesenchymal transformed MCF-7 cell line (MCF-7-EMT), which in contrast to wild-type MCF-7 cells (MCF-7 WT) exhibit significantly increased invasive behavior in vitro and in vivo as well as increased expression of EMT-related genes (34).

S100A4 and CYR61 play important roles in EMT, invasion and metastasis by promoting cancer cell motility $(6,11,38,39)$. We found both genes highly expressed in high invasive MDA-MB-231 breast cancer cells. Jiang et al demonstrated a significant increase of CYR61 expression in breast cancers in comparison to normal breast tissue (40). This increase is correlated with poor prognosis, lymph node status as well as metastatic propagation $(40,41)$. Jenkinson et al showed a clear influence of S100A4 on invasiveness of breast cancer cells (42). Invasion of breast cancer cells with S100A4 overexpression 
was strongly increased as compared with the non-transfected controls.

MCF-7 cells have no invasive behavior. In addition, MCF-7 cells show very low expression of S100A4 and CYR61. After mesenchymal transition, invasion and expression of S100A4 and CYR61 of MCF-7 cells were found to be markedly increased. The increased invasion of MCF-7-EMT cells was reduced by anti-S100A4 and anti-CYR61 antibodies. In addition, invasion of naturally high invasive MDA-MB-231 cells was decreased by anti-S100A4 and anti-CYR61 antibodies showing the important role of these factors. Nguyen et al have attributed the migration-promoting effect of CYR61 to MMP-1 expression (43). In a fibroblast-directed migration assay, loss of CYR61 in breast cancer cells led to inhibition of MMP-1. In the same assay, absence of MMP-1 activity in the fibroblasts inhibited CYR61-permitted migration of the breast cancer cells (43).

Previously we showed that in vitro invasion and in vivo metastasis of GnRH receptor-positive breast cancer cells is time- and dose-dependently reduced by GnRH analogs $(31,32)$. Now we have analyzed whether GnRH treatment affects increased invasion and expression of S100A4 and CYR61 in mesenchymal transformed breast cancer cells. Treatment of mesenchymal transformed MCF-7-EMT and naturally high invasive MDA-MB-231 cells with GnRH agonist Triptorelin resulted in a significant decrease of invasion and expression of S100A4 and CYR61. Lin et al reported that neutralizing of CYR61 using an anti-CYR61 antibody resulted in inhibition of breast cancer growth and metastasis in vivo (44). We used a non-toxic and easy to apply GnRH agonist to reduce CYR61 and S100A4 expression. In addition, our earlier studies showed anti-metastatic activities of $\mathrm{GnRH}$ agonists without undesirable side effects $(31,32)$. However, overexpression of CYR61 in endometriosis could not be reduced after therapy with GnRH agonist Leuprorelin (45).

To further show the clinical significance of S100A4 and CYR6, we have analyzed their expression in biopsy specimens. Both, S100A4 and CYR61 were found highly expressed in biopsy specimens of malignant breast cancers, whereas their expression in carcinoma in situ was much lower. Normal breast tissues and benign fibroadenoma were S100A4 and CYR61 negative. Noteworthy, we found in breast hyperplasia a high expression as well, although its biological background and relevance remains uncertain. High CYR61 expression but not high S100A4 expression seems to be associated with high estrogen receptor $\alpha(\mathrm{ER} \alpha)$ expression. It is known that expression of CYR61 is induced by estrogen (18). Correlation of high CYR61 expression with high ER $\alpha$ expression was found in many studies $(18,46-49)$. However, benign fibroadenoma with high ER $\alpha$ expression remained CYR61 negative, indicating that additional mechanisms regulate CYR61 expression.

To use GnRH agonists for treatment of invasive breast cancer it is essential that these tumors express GnRH receptors. We found $\mathrm{GnRH}$ receptor expression in approximately $71 \%$ of malignant breast cancers $(n=31)$. In a recent study we were able to demonstrate GnRH receptor expression in approximately $74 \%$ of triple-negative breast cancer specimens $(n=42)(30)$. Another study found GnRH receptor expression in all analyzed triple-negative breast cancers $(n=16)(50)$.
In conclusion, our findings suggest that S100A4 and CYR61 play major roles in breast cancer invasion. Treatment with GnRH agonist Triptorelin decreases invasion and expression of S100A4 and CYR61. The precise mechanisms remain unclear and are part of our current research. The use of GnRH agonists or similar S100A4 and CYR61 blocking treatments might represent novel anti-metastatic therapeutic approaches and should be further explored.

\section{Acknowledgements}

We would like to thank Sonja Blume for her excellent technical assistance.

\section{References}

1. Stein U, Arlt F, Walther W, Smith J, Waldman T, Harris ED, Mertins SD, Heizmann CW, Allard D, Birchmeier W, et al: The metastasis-associated gene S100A4 is a novel target of betacatenin/T-cell factor signaling in colon cancer. Gastroenterology 131: 1486-1500, 2006

2. Ito $\mathrm{M}$ and Kizawa K: Expression of calcium-binding S100 proteins A4 and A6 in regions of the epithelial sac associated with the onset of hair follicle regeneration. J Invest Dermatol 116: 956-963, 2001.

3. Mazzucchelli L: Protein S100A4: Too long overlooked by pathologists? Am J Pathol 160: 7-13, 2002.

4. Morris RJ, Liu Y, Marles L, Yang Z, Trempus C, Li S, Lin JS, Sawicki JA and Cotsarelis G: Capturing and profiling adult hair follicle stem cells. Nat Biotechnol 22: 411-417, 2004.

5. Tumbar T, Guasch G, Greco V, Blanpain C, Lowry WE, Rendl M and Fuchs E: Defining the epithelial stem cell niche in skin. Science 303: 359-363, 2004.

6. Grum-Schwensen B, Klingelhofer J, Berg CH, El-Naaman C, Grigorian M, Lukanidin E and Ambartsumian N: Suppression of tumor development and metastasis formation in mice lacking the S100A4(mts1) gene. Cancer Res 65: 3772-3780, 2005.

7. Saleem M, Kweon MH, Johnson JJ, Adhami VM, Elcheva I, Khan N, Bin Hafeez B, Bhat KM, Sarfaraz S, Reagan-Shaw S, et al: S100A4 accelerates tumorigenesis and invasion of human prostate cancer through the transcriptional regulation of matrix metalloproteinase 9. Proc Natl Acad Sci USA 103: 14825-14830, 2006.

8. Mahon PC, Baril P, Bhakta V, Chelala C, Caulee K, Harada T and Lemoine NR: S100A4 contributes to the suppression of BNIP3 expression, chemoresistance, and inhibition of apoptosis in pancreatic cancer. Cancer Res 67: 6786-6795, 2007.

9. Lau LF and Lam SC: The CCN family of angiogenic regulators: The integrin connection. Exp Cell Res 248: 44-57, 1999.

10. Holbourn KP, Acharya KR and Perbal B: The CCN family of proteins: Structure-function relationships. Trends Biochem Sci 33: 461-473, 2008.

11. Kireeva ML, Mo FE, Yang GP and Lau LF: Cyr61, a product of a growth factor-inducible immediate-early gene, promotes cell proliferation, migration, and adhesion. Mol Cell Biol 16: 1326-1334, 1996.

12. Schütze N, Schenk R, Fiedler J, Mattes T, Jakob F and Brenner RE: CYR61/CCN1 and WISP3/CCN6 are chemoattractive ligands for human multipotent mesenchymal stroma cells. BMC Cell Biol 8: 45, 2007.

13. Lin BR, Chang CC, Chen LR, Wu MH, Wang MY, Kuo IH, Chu CY, Chang KJ, Lee PH, Chen WJ, et al: Cysteine-rich 61 (CCN1) enhances chemotactic migration, transendothelial cell migration, and intravasation by concomitantly up-regulating chemokine receptor 1 and 2. Mol Cancer Res 5: 1111-1123, 2007.

14. O'Brien TP and Lau LF: Expression of the growth factor-inducible immediate early gene cyr61 correlates with chondrogenesis during mouse embryonic development. Cell Growth Differ 3: 645-654, 1992

15. Dornbach LM and Lyons KM: Genetic analysis of CCN gene function in mammalian development. In: CCN Proteins. A New Damily of Cell Growth and Differentiation Regulators. Perbal BV and Takigawa M (eds). Imperial College Press, London; Hackensack, NJ, pp135-152, 2005. 
16. Brigstock DR: Regulation of angiogenesis and endothelial cell function by connective tissue growth factor (CTGF) and cysteine-rich 61 (CYR61). Angiogenesis 5: 153-165, 2002.

17. Sun ZJ, Wang Y, Cai Z, Chen PP, Tong XJ and Xie D: Involvement of Cyr61 in growth, migration, and metastasis of prostate cancer cells. Br J Cancer 99: 1656-1667, 2008.

18. Xie D, Miller CW, O'Kelly J, Nakachi K, Sakashita A, Said JW, Gornbein $\mathbf{J}$ and Koeffler HP: Breast cancer. Cyr61 is overexpressed, estrogen-inducible, and associated with more advanced disease. J Biol Chem 276: 14187-14194, 2001.

19. Xie D, Yin D, Tong X, O'Kelly J, Mori A, Miller C, Black K, Gui D, Said JW and Koeffler HP: Cyr61 is overexpressed in gliomas and involved in integrin-linked kinase-mediated Akt and beta-catenin-TCF/Lef signaling pathways. Cancer Res 64: 1987-1996, 2004.

20. Kok SH, Chang HH, Tsai JY, Hung HC, Lin CY, Chiang CP, Liu CM and Kuo MY: Expression of Cyr61 (CCN1) in human oral squamous cell carcinoma: An independent marker for poor prognosis. Head Neck 32: 1665-1673, 2010.

21. Holloway SE, Beck AW, Girard L, Jaber MR, Barnett CC Jr, Brekken RA and Fleming JB: Increased expression of Cyr61 (CCN1) identified in peritoneal metastases from human pancreatic cancer. J Am Coll Surg 200: 371-377, 2005.

22. Chen PP, Li WJ, Wang Y, Zhao S, Li DY, Feng LY, Shi XL, Koeffler HP, Tong XJ and Xie D: Expression of Cyr61, CTGF, and WISP-1 correlates with clinical features of lung cancer. PLoS One 2: e534, 2007.

23. Chien W, Kumagai T, Miller CW, Desmond JC, Frank JM, Said JW and Koeffler HP: Cyr61 suppresses growth of human endometrial cancer cells. J Biol Chem 279: 53087-53096, 2004.

24. Evtimova V, Zeillinger R and Weidle UH: Identification of genes associated with the invasive status of human mammary carcinoma cell lines by transcriptional profiling. Tumour Biol 24: 189-198, 2003.

25. Goodwin CR, Lal B, Zhou X, Ho S, Xia S, Taeger A, Murray J and Laterra J: Cyr61 mediates hepatocyte growth factor-dependent tumor cell growth, migration, and Akt activation. Cancer Res 70 2932-2941, 2010.

26. Fekete M, Wittliff JL and Schally AV: Characteristics and distribution of receptors for [D-TRP6]-luteinizing hormone-releasing hormone, somatostatin, epidermal growth factor, and sex steroids in 500 biopsy samples of human breast cancer. J Clin Lab Ana 3: 137-147, 1989.

27. Baumann KH, Kiesel L, Kaufmann M, Bastert G and Runnebaum B: Characterization of binding sites for a GnRHagonist (buserelin) in human breast cancer biopsies and their distribution in relation to tumor parameters. Breast Cancer Res Treat 25: 37-46, 1993.

28. Moriya T, Suzuki T, Pilichowska M, Ariga N, Kimura N, Ouchi N, Nagura $\mathrm{H}$ and Sasano $\mathrm{H}$ : Immunohistochemical expression of gonadotropin releasing hormone receptor in human breast carcinoma. Pathol Int 51: 333-337, 2001.

29. Mangia A, Tommasi S, Reshkin SJ, Simone G, Stea B, Schittulli F and Paradiso A: Gonadotropin releasing hormone receptor expression in primary breast cancer: Comparison of immunohistochemical, radioligand and western blot analyses. Oncol Rep 9: $1127-1132,2002$

30. Fost C, Duwe F, Hellriegel M, Schweyer S, Emons G and Grundker C: Targeted chemotherapy for triple-negative breast cancers via LHRH receptor. Oncol Rep 25: 1481-1487, 2011.

31. von Alten J, Fister S, Schulz H, Viereck V, Frosch KH, Emons G and Gründker C: GnRH analogs reduce invasiveness of human breast cancer cells. Breast Cancer Res Treat 100: 13-21, 2006.

32. Schubert A, Hawighorst T, Emons G and Gründker C: Agonists and antagonists of GnRH-I and -II reduce metastasis formation by triple-negative human breast cancer cells in vivo. Breast Cancer Res Treat 130: 783-790, 2011.
33. Gründker C, Schlotawa L, Viereck V, Eicke N, Horst A, Kairies B and Emons G: Antiproliferative effects of the GnRH antagonist cetrorelix and of GnRH-II on human endometrial and ovarian cancer cells are not mediated through the GnRH type I receptor. Eur J Endocrinol 151: 141-149, 2004

34. Ziegler E, Hansen MT, Haase M, Emons G and Gründker C: Generation of MCF-7 cells with aggressive metastatic potential in vitro and in vivo. Breast Cancer Res Treat 148: 269-277, 2014

35. Gründker C, Bauerschmitz G, Knapp J, Schmidt E, Olbrich T and Emons G: Inhibition of SDF-1/CXCR4-induced epithelialmesenchymal transition by kisspeptin-10. Breast Cancer Res Treat 152: 41-50, 2015

36. Olbrich T, Ziegler E, Türk G, Schubert A, Emons G and Gründker C: Kisspeptin-10 inhibits bone-directed migration of GPR54-positive breast cancer cells: Evidence for a dose-window effect. Gynecol Oncol 119: 571-578, 2010.

37. Magliocco A and Egan C: Breast cancer metastasis: Advances trough the use of in vitro co-culture model systems. In: Breast Cancer - Focusing Tumor Microenvironment, Stem Cells and Metastasis. Gunduz M and Gunduz E (eds). InTech, Rijeka, Croatia, 2011. doi: 10.5772/21743.

38. Kim EJ and Helfman DM: Characterization of the metastasisassociated protein, S100A4. Roles of calcium binding and dimerization in cellular localization and interaction with myosin. J Biol Chem 278: 30063-30073, 2003

39. Leask A and Abraham DJ: All in the CCN family: Essential matricellular signaling modulators emerge from the bunker. J Cell Sci 119: 4803-4810, 2006.

40. Jiang WG, Watkins G, Fodstad O, Douglas-Jones A, Mokbel K and Mansel RE: Differential expression of the CCN family members Cyr61, CTGF and Nov in human breast cancer. Endocr Relat Cancer 11: 781-791, 2004.

41. Xie D, Nakachi K, Wang H, Elashoff R and Koeffler HP: Elevated levels of connective tissue growth factor, WISP-1, and CYR61 in primary breast cancers associated with more advanced features. Cancer Res 61: 8917-8923, 2001.

42. Jenkinson SR, Barraclough R, West CR and Rudland PS: S100A4 regulates cell motility and invasion in an in vitro model for breast cancer metastasis. Br J Cancer 90: 253-262, 2004.

43. Nguyen N,Kuliopulos A, Graham RA and Covic L: Tumor-derived Cyr61(CCN1) promotes stromal matrix metalloproteinase-1 production and protease-activated receptor 1-dependent migration of breast cancer cells. Cancer Res 66: 2658-2665, 2006.

44. Lin J, Huo R, Wang L, Zhou Z, Sun Y, Shen B, Wang R and Li N: A novel anti-Cyr61 antibody inhibits breast cancer growth and metastasis in vivo. Cancer Immunol Immunother 61: 677-687, 2012.

45. Absenger Y, Hess-Stumpp H, Kreft B, Krätzschmar J, Haendler B Schütze N, Regidor PA and Winterhager E: Cyr61, a deregulated gene in endometriosis. Mol Hum Reprod 10: 399-407, 2004.

46. Dhar A and Ray A: The CCN family proteins in carcinogenesis. Exp Oncol 32: 2-9, 2010.

47. Tsai MS, Bogart DF, Castañeda JM, Li P and Lupu R: Cyr61 promotes breast tumorigenesis and cancer progression. Oncogene 21: 8178-8185, 2002

48. Tsai MS, Bogart DF, Li P, Mehmi I and Lupu R: Expression and regulation of Cyr61 in human breast cancer cell lines. Oncogene 21: 964-973, 2002

49. Sampath D, Winneker RC and Zhang Z: Cyr61, a member of the $\mathrm{CCN}$ family, is required for MCF-7 cell proliferation: Regulation by 17 beta-estradiol and overexpression in human breast cancer. Endocrinology 142: 2540-2548, 2001.

50. Buchholz S, Seitz S, Schally AV, Engel JB, Rick FG, Szalontay L, Hohla F, Krishan A, Papadia A, Gaiser T, et al: Triple-negative breast cancers express receptors for luteinizing hormonereleasing hormone $(\mathrm{LHRH})$ and respond to LHRH antagonist cetrorelix with growth inhibition. Int J Oncol 35: 789-796, 2009. 